[Stuart, D. (2006). Commercial School-Business Relationships in New Zealand. New Zealand Annual Review of Education, 15, 65-83]

\section{Commercial School-Business Relationships in New Zealand}

\section{DAVID STUART}

\section{Abstract:}

This article explores contemporary commercial school-business relationships in New Zealand schools, in a context of intensifying of child-business relationships, and in particular the blurring of once clear boundaries between children's learning, their entertainment experiences, and the commercial efforts of corporate marketing and public relations. These child-business relationships in turn arise through contemporary consumer capitalism, and three problematic features of this economy are considered: inequality, commodification and globalisation. The last part of the article considers how schools are currently managing their commercial school-business relationships, with a particular emphasis on classroom teachers, and curriculum-related materials and programmes. It is suggested that schools are responding to children who are different because of their changing social status through consumption. However, in terms of school-business relationships, this response has yet to extend beyond using commercialised popular culture to motivate and engage, into a more critical examination of these relationships and of commercial culture generally.

$\mathrm{D}$

cumented critical interest in commercial school-business relationships, what some call schoolhouse commercialism or school commercialism, has waxed and waned in New Zealand since the Tomorrow's Schools administration and curriculum reforms of the 1990s. However, public anxiety over these relationships was on something of a high in 2005, as the in-school marketing and selling of foods of minimal nutritional value (sometimes for fundraising purposes), was challenged by health professionals and a public concerned about New Zealand's child "obesity epidemic".

But a part from this blip in public and professional scrutiny of school commercialism, there is a sense that the issue has gone quiet after an expectation of "new times" in the mid-1990s, and some novel and high profile relationships (such as school naming rights sponsorships and bank advertisements on NZQA exam papers). As one principal expressed to me:

It's [school-business relationships] not, even with some principals with pretty left wing traditions, yeah, it's not something that gets their blood up at all really.

This article examines commercial school-business relationships in a context of changing child-business relationships, and with reference to identified problems with consumer capitalism: inequality, commodification, and aspects of globalisation. The responses of New Zealand educators to commercial school-business relationships are then considered and discussed.

Before examining contemporary school-business relationships in New Zealand through a school commercialism frame, it is important to note that there is a tendency in the critical literature to homogenise school and business motives. While I would argue that the commercial context is pervasive as a basis for school-business relationships in New Zealand, there are two further business arguments for these associations which depend on different models of relationship - school-business relationships for corporate social responsibility, and enterprise education frameworks. Both these approaches to some extent challenge businesses and schools to move away from relationships based on commercial motives (New Zealand Business Council for Sustainable Development, 2001; Ministry of Education, 1999).

\section{Business Motives and Strategies for Commercial School-Business} Relationships

Contemporary commercial school-business relationships can be considered as part of an intensifying marketing relationship between young people and corporations. Children have, of course, been consumers for a long time. Seiter (1993) shows that in the early 20th Century the growing sentimentalisation of children and the influence of psychological child development theories saw the rise of advertising to parents for child-related products. After World War Two, advertisers turned their attention to the "youth market" in earnest, on the back of television, a baby boom, and a strong economy, leading to segmentation of advertising along adult and child market lines (McNeal, 1992). In the 1980 s, the marketing of child-related goods and services to parents and 
children expanded enormously (Buckingham, 2000; Buckingham \& Scanlon, 2003). Figures from the USA show that child advertising budgets rose by as much as 2000 percent from 1987-1997, to an estimated 15 billion dollars per annum in 2004 (Molnar, 1998; Wolcott, 2004). Today, the child consumer is lauded by marketing analysts as three separate markets - an instant purchaser, a future consumer, and in their most financially lucrative form - an influencer of parent spending (McNeal, 1992).

Of perhaps greater significance to educators than the rise of the child as an advertising target per se, are changes in the nature of these marketing relationships. Childhood is shared with an ever-expanding list of corporations as children's spheres (including elements of their learning) are progressively commodified and commercialized. Advertising blends with entertainment and learning in toys, movies, fast food, and new "edutainment" offerings such as interactive websites. This de-differentiation of advertising from learning and play is partly enabled by the spectacular recent growth in child media channels. In the 1960s corporations were limited in their direct communication opportunities with youth to TV, radio, records, movies and books. New media forms, many of which are user pays or funded through advertising, include email, instant messaging, mobile phones, various broadcast platforms, the internet, online gaming, video streaming and a host of other platforms (Roberts et al., 2005). Contemporary schoolbusiness relationships are part of this merging of children's play, learning and consumption. So, for instance, sponsored educational materials from the fast-food industry incorporate branding, messages and activity elements aligned with the wider marketing effort.

The discussion above suggests a marketing orientation to business motives. However businesses have also worked through schools in the "softer" commercial area of public relations. Public relations (PR), simply defined, is the sustained effort by an organisation to establish mutual understandings with diverse publics (Peart \& Macnamara, p. 16). Although this role is suggestive of education, the industry itself made an early distinction between the two practices:

Regardless of the varying definitions of public relations, most authorities will agree that the accepted practice of public relations is the presentation of truth as an individual or a group sees it, in an effort to gain common acceptance of that truth. Human nature being what it is, there are few who believe they are called upon to present the disadvantages of an idea or cause as well as the advantages. Thus public relations is, in practice, advocacy. Education provides for the presentation of all sides of a question, or it has in the past....While public relations is frequently referred to as an educational process, we know of no public relations programmes which promote a cause or an idea by debating both advantages and disadvantages .... Education seeks to establish and teach truths. Public relations advocates what is accepted by an individual or a group as a truth. (Jones, 1955, p. 157)

Since the 1970s corporate public relations has assumed a harder commercial purpose, as image has become vital to commercial success. More consumers now seek to purchase from businesses that appear to be socially responsible, and poor corporate behaviour has been punished at the cash register (Young 1996; Payne et al., 1995). Ries and Ries (2002) argue that public relations has replaced advertising as the leading brand development strategy, as consumers become more cynical and resistant to advertising, but respond positively to third party endorsements of companies and products. This elevation of PR has seen it merge with marketing functions, giving rise to "image marketing" (Marconi, 1996).

As corporate PR has evolved, schools have continued to be a target for the consumption of corporate world-views, but also increasingly as a "re-producer" of corporate narratives. As far as this "consumption" role is concerned, corporate presentations of the "truth" around particular issues or softer image strategies feed into schools through sponsored educational materials and programmes, including a prominent flow from businesses and industries working in publicly sensitive contexts (Harty, 1979; Consumers Union Education Services, 1995; Wilson, 2002). Schools have also been used in a "production" role, which sees them actively or unconsciously reproducing and affirming particular corporate images to wider publics - again sometimes associated with risk-prone industries. This role ranges from school promotion to parents, to wider public promotion of school-business relationships by sponsors (through, for instance, newspaper advertisements and annual reports to shareholders), to submission of this evidence of corporate social responsibility to governments, in order to manage these relations (Carter, 2003). An example of this latter strategy was seen to be in effect when the anti-youth smoking school resource I've Got the Power was found to be funded by tobacco multinational Philip Morris. Appalled educators argued that this strategy was part of an attempt by Philip Morris to manage the risk of 
further regulation by being able to argue to government that the company was being socially responsible ("Principals vow to stub out packs," 1999, p. 1).

\section{Examining Children and Schools in Consumer Culture}

A critical examination by educators of the ways in which schools and students are positioned within the marketing and public relations efforts of businesses should cover both the risks and pedagogical implications of contemporary consumer capitalism. In terms of risk, Holt and Schor (2000) describe three core elements of current anxiety over consumer culture: inequality, commodification and globalisation.

\section{Inequality}

Inequality focuses on the socio-economic extremes of consumption, with a wealthy, overworked, over-consuming, indebted middle-class, separated by their purchasing power from an aspiring, consuming, poor. Within this view, consumption becomes a key arbiter of social inequality, as we are judged rich or poor by what we consume rather than by what we do for a job or earn. Hence corporations, through their advertising, structure and restructure these lines between the haves and the have-nots. While debate about education's role in the reproduction of inequalities has focused on the school-labour market link (Bowles \& Gintis, 1976), and on cultural preferences (Apple, 1995), how schools embed or disrupt cultural differences established through consumption is not so frequently discussed. Yet, in a rare analysis, Spring (2003) has shown how even "un-hidden" school curriculum change in the 20th century was often the servant of emerging consumer markets.

\section{Commodification}

The second of Holt and Schor's concerns with consumer society is commodification: the surrender of childhood social experiences to the lure of commodities, including their sale. Such is the integration of the child into the adult world of marketing and consumption that some authors have asserted a "death of childhood" (Postman, 1994). Others claim that children are now "born to buy" and have replaced baby boomers as the marketing pace-setters (Schor, 2005); still others argue that an entirely new commercialized "kinderculture" has emerged (Steinberg \& Kincheloe, 1997). Although not everyone follows such a pessimisticline (Buckingham, 2000; Kenway \& Bullen, 2001), most critics working in a cultural studies frame agree that the social construction of childhood has been significantly altered through consumption - that childhood has indeed changed. Childhood commodification allows various businesses to be influential in the regulation of child-parent relations and the social status of children. This corporatised kinderculture is seen to encourage consumption, but also promote values of non-empathy, cynicism, "rugged individualism", and a fascination with surface spectacle and the image value of things rather than depth. All of these are seen to further consumption as a complete way of life and challenge a social justice agenda. As childhood identity marches more in tune with the commercial designs of corporations, deference for the traditional learning logic and adult authority of schools is also disrupted (Kenway \& Bullen, 2001).

\section{Globalisation}

The third element of Holt and Schor's critique of consumption is globalisation, and in particular the sometimes problematic global trade dynamics that are embedded in consumer capitalism. Maintaining Western consumption lifestyles requires the massive production of cheap goods in low wage economies, which are then transported and marketed to first world consumers. The criticism of this accelerated global trade to satiate rising consuming desires is multifaceted. However, two central concerns are:

- the ecological effects of the resource extraction necessary to meet consumers' demands;

- the uneven and disruptive economic and cultural effects of global trade.

In this second area, some critics focus on the collapse of local economies when manufacturing shifts "off-shore" or goods simply become too expensive to compete against cheap imports (Downs, 1995). Others stress the cultural shift away from local tradition to homogenising largely western practices and preferences (Barber, 2002). Yet others protest the financial vulnerability and exploitation of third world factory workers and producers (Klein, 2000). How students, who now consume more of these branded goods and low cost services than any previous childhood generation, should be implicated in the ecological, economic and cultural effects of global trade is a legitimate education question tricky, but under the circumstances, not radical.

What is doubly worrying about educators who leave these moral issues of commodity production to one side is that schools and students 
are sought out by the very businesses and industries that are vulnerable to this critique. Since Harty's 1979 analysis of school-business relationships in the United States, businesses and industries that have fragile reputations - most notably those that are charged with over-exploitation of natural resources and those marketing foods of minimal nutritional value - have been found to be most likely to supply curriculum materials and programmes to schools (See also Consumers Union Education Services, 1995). In New Zealand, Wilson (2002) found a long list of resource extraction companies and industry associations providing materials and programmes to schools, or sponsoring the educational programmes of others. These included Shell Oil, BP, Waihi Gold Mining Company, The New Zealand Minerals Industry Association, and the Plastics Environmental Advisory Council. Internationally, the entry of such businesses into schools has often coincided with a severe loss of public confidence in their business practices. Hager and Burton (1999) in their analysis of the primary planning documents of New Zealand State Owned Enterprise (SOE), Timberlands, for a school resource kit on "sustainable logging" of native West Coast timber, found that the desire to produce and distribute this kit was governed by a singular goal to re-educate students, who it was felt were developing a position that negatively impacted on Timberlands' operations.

\section{How Schools Currently Manage Commercial School-Business \\ Relationships}

The previous section shows that commercial school-business relationships are part of a new type of child-business relationship that gives rise to sophisticated business strategies in schools and other childhood spheres. Further, that the consumption economy and culture which are advanced through these processes are not without their problems and educational implications. This section, drawing on my own research interviews and surveys with primary school educators in New Zealand, plus some international literature, considers how New Zealand schools currently construct and manage such relationships.

The international literature is not short of critics of the commercial business motive in schools, who have argued that it disrupts the democratic role of schooling by giving over education time to institutions whose profit-maximizing agendas produce programmes and resources that encourage consumption and the development of a consuming subject, rather than a critical rational subject (Molnar, 2005). By contrast, there is relatively little published research on this issue, or indeed any kind of theory building or elaboration of school motives and responses. Some authors have linked commercial school-business relationships to wider aspects of commodification and commercialising tendencies in public education. They argue that a new cultural agenda has driven policy change, and pervaded school decision making, devaluing outcomes associated with critical citizenship and social justice and transformation, and elevating cultural reproduction tendencies and economic efficiency (Apple, 1996; Saltman \& Gabbard, 2003; Giroux, 2000). More tangibly, some argue that school reform has left schools, and particularly those serving poor students, with little choice but to take the resources and funds on offer from business (Molnar 1996; Breault, 1995; Morgan, 1993). ${ }^{2}$

Boyles $(2000,2005)$ has considered the changing of teachers' work within the cultural conditions of what he terms "consumer materialism". He argues that educators have become susceptible to dubious commercial offerings because their professional environment discourages an ethical and critical disposition in favour of one which rewards the efficient transfer of pre-packaged knowledge. This leads to a failure by teachers to connect the "here and now" offerings from businesses with wider social, economic and political problems, for instance, those of consumer capitalism. While Boyles offers this theory for more recent use of sponsored materials, Giroux and Simon (1989) argue that there has never been a golden age of critical engagement with commercialised popular culture by teachers. Within their view, the progressive Left in education has seen popular culture onedimensionally and negatively as a means to socialise the "masses" into an existing social order, or as an element of folk culture - something to be acknowledged as cultural and authentic but not fundamental to identity and individuals' knowledge construction. Conservatives have extended this marginalization of popular culture from the cultural "mainstream" by associating it with vulgarity and deviance - including youth deviance. This view calls on schools to defer to the classic artistic, scientific and literary works of enlightenment culture, and of course much debate surrounds the place of alternative knowledges in the curriculum.

Critiques of school-business relationships based around the problems of business motive appear to have gained little actual traction with educators. When research with large samples has been undertaken 
around school motives and strategy for school-business relationships, principals have expressed cautious optimism or resigned pragmatism about their commercial relationships - citing the benefits of additional resources, enhancement of the curriculum, the implicit value of community partnerships, and school image/identity benefits (di Bona et al., 2003; Wilkin et al., 2005):

It is not that principals are unaware of the dangers of commercialism in their schools, but rather that they place the immediate needs of their students ahead of the long-term and the less-certain health and psychological damage. (di Bona et al., 2003, p. 59)

In my own research in primary schools, I found three ways commercial school-business relationships came to be adopted in schools, each underlined by a different rationale, and managed by different people.

\section{Complex and/or Financial Relationships}

Complex and/or financial relationships were typically sponsorships, partnerships and the more time-intensive sponsored educational programmes. Principals would manage and sometimes cultivate these relationships and pass on proposals for Board of Trustees deliberation and approval. While these proposals could be subject to input from the school management team, teachers generally did not lead this decision-making. Principals brought three facets of their role to their decision-making: those of educational leader, school manager (including financial manager), and ethical role model. They were sometimes very perceptive about how education reforms had placed these roles in tension and this did not always sit comfortably with them. One commented:

I think that generally the Tomorrow's Schools thing and the politics that that comes from, has kind of opened up a whole bunch of new thinking in education you know, the entrepreneurial type thinking, the promotion of this school over that school type scenario. And that has probably changed some peoples' thinking about "How do I do that?" And a lot of my colleagues have adopted a real business approach to how they do things you know the promotion of the school, the touting for business, the looking for clients as opposed to looking for students that kind of thinking that has come into it. And so the link to businesses has become easier because all of a sudden educators were, at least in part, talking a business kind of language. And I don't necessarily see that as a positive because I don't come from that kind of a philosophy if you like, but definitely then, the side-kick to that I think is that schools are in more need of sponsorship and in more need of money and in more need of those things because they are desperately trying to make ends meet. So the entrepreneurial character that was able to get more funding for the school and implement more programmes has probably done all right for him or herself.

Principals demonstrated a generally higher level of understanding of the business commercial motive than was evident with teachers. They also had expectations of critical assessment of materials and programmes by teachers. When asked to unpack the business motive, principals were most sure about businesses wanting to market products to a captive audience of students, followed by a drive to present their point of view to students. Marketing and PR targets external to the school were mentioned only in terms of children's "nag-factor" influence on parent spending, except for one principal who suggested that government could be the ultimate audience. What worried principals more than a commercial motive per se was the risk of business relationships being over-bearing, disruptive, or in any way "high maintenance" for the school. Principals clearly wanted teachers to have a strong degree of control within the relationship, and not as one put it, be "dictated to".

\section{Fundraising relationships}

Decision-making around business-backed fundraising opportunities was dominated by the Parent Teacher Association (PTA) or equivalent fundraising/school support committees, and sometimes undertaken fairly autonomously by these groups. These groups were highly motivated by fundraising targets and were operating in an environment of dwindling parent participation in the planning and operating of fundraising. Hence the ready-made, high yield and low effort packages on offer, particularly from confectionary and fast food businesses, were popular. Again teachers were not central to this decision-making and might not be consulted at all. They often would, however, be called on to promote and administer these commercial fundraising programmes.

\section{Curiculum-related relationships}

Where teachers were essential to school-business relationship decision-making was around curriculum-related relationships. These offers included sponsored educational materials and less complex and less time-intensive sponsored educational programmes. Teachers were 
notably less certain about the business motive than principals. Like principals they tended to articulate that businesses were seeking advertising opportunities with students, leading to customer loyalty and ultimately, more sales. It wasn't until teachers were shown examples of contemporary sponsored educational materials that some mentioned the potential for businesses to package partial information for teachers and students in an effort to promote their products and perspectives.

Teachers were highly motivated by curriculum fit, and therefore severely biassed or narrowly focussed materials and programmes from business were often rejected as irrelevant:

At the end of the day, if they're free and they're no use, you won't use them, is the reality. If they're free and, but if they're pushing, if

their message doesn't link in with your curriculum you just don't use

Some teachers seemed confident that they could make these judgments about bias, yet when they were shown materials from the poultry industry, for example, none was alert to the possibility that these materials might present an industry defence of battery hen farming [which they did].

Relating to curriculum fit was ease of integration into the classroom: many sponsored materials contain explicit curriculum achievement objectives and structured classroom activities, potentially cutting down significantly on teacher preparation time:

McDonald's [the McDonald's Reading Programme] have come along and tried to turn it into something where, for me, I don't have to do any extra planning, its all been done for me. I just have to put the programme in action and I'm going to get a great result.

A third key driver for teacher adoption of curriculum-related school-business relationships, beyond utility and ease of use, was student appeal. Here there were references to children's brand desires, and student affinity with the presentation styles of popular culture. Items that contained iconic sponsors and characters, dazzling graphics and text, incentives or treats associated with sponsors' products, or were digitally-based (e.g., on internet or CD-ROM) had a generally higher chance of being accepted, even if falling short on curriculum fit.

Although teachers need to become more prominent in complex and/or financial and fundraising relationships, (not least because they can involve educationally dubious and unhealthy activities - Stuart, 2005b), I will focus here on discussing teacher responses to commercial curriculum-related relationships. Teachers' positive reactions to sponsored resources and programmes in respect of student appeal revealed a sensitivity to children's commercialized popular culture. As discussed above, children's accelerating affinity with brands and new media, and the increasing de-differentiation between learning, advertising, and play, has brought schools and popular culture into a new proximity. Teachers, in giving weight to student desires for commercial styles and brands in their decision-making about sponsored educational materials and programmes, were participating in this renegotiation of cultural boundaries. As one deputy principal described

Generally speaking the things [school-business relationships] that we undertake are things that $\mathrm{A}$ : we believe our kids need; $\mathrm{B}$ : fits in with the curriculum already; $\mathrm{C}$ : is like a cool gimmicky type thing.

The nature of this renegotiation with the popular seemed to partly depend on the social status and desires of the children being educated, which raises questions of inequality. Although all children's tastes for learning materials were seen to be affected by their non-school world, the actual treats of popular culture were seen to have greater leverage with poorer students:

They [decile 9 students] like better resources, they're not happy with the teacher-made resources. They like the posh looking stuff, but they don't want tacky rubbish up here, they want something that's good. I mean I used to work in [low decile school in a nearby town]. Now stickers for them were fantastic. Any sticker you gave them, a pencil would in fact you know - it was "thank you" they were so grateful. Here it's like" Oh so it's a pencil, right, wonderful" [sarcastic tone]. It doesn't have any value, it doesn't have any meaning to them up here, but it does where I used to work. (Teaching deputy principal)

Another teacher at a decile 1 school remarked:

They have high expectations of what they're going to get but that also depends on where you are or what school you're in or how your school is set up. I mean that really does. Our kids respond well to stickers and a cuddle here.

Wealthy parents were seen by some participants as being less inclined to tolerate the tackiness of certain brand sponsors in learning, such as McDonald's. Finally, some teachers serving poorer students spoke of the 
potential for commercial relationships to equalize educational opportunities and school status through extra classroom and extra-curricular resources. Such teachers were not at all comfortable with, or resigned to, the social inequalities around them, and saw a greater social good in some commercial opportunities.

However, this purposeful filtering in of popular culture by teachers also revealed a level of persistence of the cultural blockade between high status classroom learning and low status popular culture forms. Commercial style and content was used by teachers to extrinsically motivate and engage students for the "real" learning, rather than being considered more critically as educational. Teachers conceptually separated the marketing and learning elements of a resource or programme - they were seen as educational, but with ads - not a purposeful fusion. These advertising elements were seen as a business agenda to promote more consumption of particular products, not something that reinforced a particular social identity of consumption. Students' higher expectations of being entertained in school were framed as a challenge for teachers rather than a genuine element of student diversity that should give rise to deeper questions about teaching practice.

This incomplete acknowledgement of the consuming identities of students eliminated any educational incentive to bring students into critical tension with their consumption. The motives and strategies of sponsors and their links to the problems of consumer capitalism therefore remained largely off the agenda in teacher planning and classroom activities. Teachers did not have a strong understanding of contemporary corporate public relations strategies, and how schools might be used to consume and re-produce particular narratives for businesses and industries facing legitimacy threats. Bias or narrowness was a teacher concern, but usually not enough to elevate critique of such materials and programmes beyond curriculum fit, towards exploring these biases as conscious classroom activities. Teachers felt that they could round out some of the limits of this content with other materials and strategies, but again their decoupling of "marketing" and "learning" overlooked the more important educational deficiency of these materials, their orientation towards consent and consumption by non-critical consumers.

\section{Conclusion}

School engagement with commercial school-business relationships suggests that a pattern of renegotiation is occurring between classroom learning and children's increasingly commercialised social experiences and relationships outside of school. In a broad sense, a liberalisation of the borders between high and low culture in school is a good thing, because it acknowledges that students do not become "different" when they enter school. In a networked society, schools are literally becoming part of a global digital landscape of experiences and relationships for children. At its best, educational responses to these present realities draw on a range of useful frameworks such as "new literacies" studies for media-saturated lives (Lankshear \& Knobel, 2003), certain approaches to environmental education (for instance "eco-justice" philosophies), and at a policy level the development of future-focused "key competencies" for students. But in an era where consumption contributes to our social reality like never before, and our consumption ultimately delivers economic, social and environmental realities for local and global others, there are risks with a liberalisation founded on student engagement alone. School-business relationships are a ritual of contemporary consumer capitalism, and educators need to purposefully explore links between business offerings, students' consuming identities and consumption choices, inequality and risk.

Schools were never set up with an agenda of fostering the critical consumer, and the complexity of business motives and sophistication of business strategies in schools has to date evolved faster than the interest and understandings of educators in relation to these developments. As governments world-wide contemplate serious man-made ecological risks (such as global warming, peak oil and unsustainable resource depletion), and the social, economic and population health dilemmas of consumer capitalism, schools need to turn their attention to childbusiness relationships. The prevailing critical view of school commercialism places a great deal of faith in the development of an enlightenment rational subject who will lead future progressive change through technology solutions and the ballot. In this paradigm, schools must not be polluted by an advertising and public relations industry which stunts the development of critical and rational capacities. Yet in a society so fundamentally socialized by what citizens buy, and where learning and advertising are tending to coalesce, it is the consuming subject that educators will need to work with for progressive change.

The year 2006 could be a pivotal one for thinking about commercial 
school-business relationships, with more focus on school responsibilities in child nutrition and health. In developing strategies of compliance with any new policies or parent pressure, it might also be timely for schools to reflect more broadly on the child-business connection. This would include assessing the ways in which schools are confronting or upholding students' consuming identities through their business relationships, and what kinds of social, economic and ecological realities on a local and global scale might ultimately be resulting or persisting through these engagements.

\section{Note}

1. Some of the material for this paper is drawn from my recently completed $\mathrm{PhD}$ thesis on school-business relationships in New Zealand (Stuart, 2005a). This project included a survey of large businesses, a survey of primary school principals, a content analysis of food-related sponsored educational materials, and interviews at five primary schools.

2. In New Zealand, schools since 1989 have been shown to be under financial pressure at both ends of the spectrum - some needing money to survive in a declining roll situation (Hughes et al., 1996), and others spending up large on image and expansion (Hutchinson, 2002).

\section{References}

Apple, M. W. (1995). Education and power (2nd ed.). New York: Routledge.

Apple, M. (1996). Cultural politics and education. New York: Teachers College Press.

Barber, B. (2002). Jihad vs. McWorld. In G. Ritzer (Ed.), McDonaldisation: The reader (pp. 191-198). Thousand Oaks, CA: Pine Forge Press.

Belch, G., \& Belch, M. (1995). Introduction to advertising and promotion: An integrated marketing communications perspective (3rd ed.). Chicago: Irwin Inc.

Bowles, S., \& Gintis, H. (1976). Schooling in capitalist America: Educational reform and the contradictions of economic life. London: Routledge \& Kegan Paul.

Boyles, D. (2000). American education and corporations: The free market goes to school. New York: Falmer Press.

Boyles, D. (2005). The exploiting business: School-business partnerships, commercialization, and students as critically transitive citizens. In D. R. Boyles (Ed.), Schools or markets? Commercialism, privatization and school-business partnerships (pp. 217-240). New Jersey: Lawrence Erlbaum Associates.

Breault, D. A. (2005). Jesus in the temple: What should administrators do when the marketplace comes to school? In D. Boyles (Ed.), Schools or markets? Commercialism, privatization and school-business partnerships (pp. 59-68). New Jersey: Lawrence Erlbaum Associates.

Buckingham, D. (2000). After the death of childhood: Growing up in the age of electronic media. Cambridge: Polity Press.

Buckingham, D., \& Scanlon, M. (2003). Education, entertainment and learning in the home. Buckingham: Open University Press.

Carter, S. (2003). From legitimate consumers to public relations pawns: The tobacco industry and young Australians. Tobacco Control, 12 (Suppl. 3), 71-78.

Consumers Union Education Services. (1995). Captive kids: Commercial pressures on kids at school. New York: Consumers Union of United States, Inc.

di Bona, J., Chaudhuri, R., Jean-Baptiste, J., Menachem, P., \&Wurzburg, M. (2003). Commercialism in North Carolina high schools: A survey of principals' perceptions. Peabody Journal of Education, 78(2), 41-62.

Downs, A. (1995). Corporate executions: The ugly truth about layoffs. How corporate greed is shattering lives, companies and communities. New York: American Management Association.

Giroux, H. (2000). Stealing innocence: Corporate culture's war on children. New York: Palgrave.

Giroux, H., \& Simon, R. (1989). Popular culture, schooling and everyday life. Granby, MA: Bergin and Garvey.

Hager, N., \& Burton, B. (1999). Secrets and lies: The anatomy of an anti-environmental PR campaign. New Zealand: Craig Potton Publishing.

Harty, S. (1979). Hucksters in the classroom: A review of industry propaganda in schools. Washington, D.C: Center for the Study of Responsive Law.

Holt, D., \& Schor, J. (2000). Introduction. Do Americans consume too much? In J. Schor \& D. Holt (Eds.), The consumer society reader (pp. vii-xxiii). New York: The New Press.

Hughes, D., Lauder, H., Watson, S., Hamlin, J., \& Simiyu, I. (1996). 
Markets in education: Testing the polarisation thesis. The Smithfield Project Phase 2. Wellington: Ministry of Education.

Hutchinson, M. (2002). Education marketing: selling or serving public education? The response of Auckland secondary school principals to the marketing imperatives in New Zealand education. Unpublished Master of Educational Management Thesis, UNITEC Institute of Technology, Auckland.

Jones, J. (1955). Organisation for public relations. In E. L .Bernays (Ed.), The engineering of consent (pp. 156-184). Norman, OK: University of Oklahoma Press.

Kenway, J., \& Bullen, E. (2001). Consuming children: Education, entertainment, advertising. Buckingham: Open University Press.

Klein, N. (2000). No $\log o$. London: Flamingo.

Lankshear, C., \& Knobel, M. (2003). New literacies: Changing knowledge and classroom learning. Buckingham: Open University Press.

Marconi, J. (1996). Image marketing: Using public perceptions to attain business objectives. Chicago: NTC Business Books.

McNeal, J. (1992). Kids as consumers: A handbook of marketing to children. New York: Lexington Books.

Ministry of Education. (1999). Working together: Building partnerships between schools and enterprises. (Revised ed.). Wellington: Ministry of Education.

Molnar, A. (1996). Giving kids the business: The commercialisation of America's schools. Colorado: Westview Press.

Molnar, A. (1998). Sponsored schools and commercialised classrooms: Schoolhouse commercialising trends in the 1990s. Milwaukee: University of Wisconsin, Centre for the Analysis of Commercialism in Education (CACE).

Molnar, A. (2005). School commercialism: From democratic ideal to market commodity. New York: Routledge.

Morgan, M. (1993). Channel One in the public schools: Widening the gaps. Amherst, MA: University of Massachusetts.

New Zealand Business Council for Sustainable Development. (2001). Successful business and school partnerships: Making a difference for a sustainable New Zealand. Auckland: New Zealand Business Council for Sustainable Development.
Payne, A., Christopher, M., Clark, M., \& Peck, H. (1995). Relationship marketing for competitive advantage: Winning and keeping customers. Oxford: Butterworth-Heinemann.

Peart, J., \& Macnamara, J. (1996). The New Zealand public relations handbook (2nd ed.). Palmerston North: Dunmore Press.

Postman, N. (1994). The disappearance of childhood. New York: Vintage Books.

Principals vow to stub out packs. (1999, January 20). New Zealand Herald, p. 1.

Ries, A., \& Ries, L. (2002). The fall of advertising and the rise of PR. New York: Harper-Collins Publishers.

Roberts, D., Foehr, U., \& Rideout, V. (2005). Generation M: Media in the lives of 8-18 year-olds.

$<$ www.kff.org/entmedia/loader.cfm?url=/commonspot/security/ getfile.cfm\&PageID =51809> (Accessed March 2005). Kaiser Family Foundation.

Saltman, K., \& Gabbard, D. (Eds.) (2003). Education as enforcement - The militarization and corporatization of schools. New York: RoutledgeFalmer.

Schor, J. (2005). Born to buy: The commercialized child and the new consumer culture. New York: Scribner.

Seiter, E. (1993). Sold separately. Parents and children in consumer culture. New Brunswick, New Jersey: Rutgers University Press.

Spring, J. (2003). Educating the consumer-citizen: a history of the marriage of schools, advertising, and media. New Jersey: Lawrence Erlbaum Associates.

Steinberg, S., \& Kincheloe, J. (Eds.) (1997). Kinderculture: The corporate construction of childhood. Boulder, Colorado: Westview Press.

Stuart, D. (2005a). Pedagogies of the best dressed: School-business relationships in New Zealand 1990-2004, including the case of food. Unpuplished PhD thesis, Victoria University of Wellington.

Stuart, D. (2005b). Educator responses to food-related school business relationships from a socio-ecological and health promotion perspective. Ministry of Education Curriculum Project Paper.

<www.tki.org.nz/r/nzcurriculum/docs/edu-response-nov2005.doc > (Accessed February 2006).

Wilkin, A., Kendall, S., White, R., Kinder, K., Bojke, C., Johnson, F. 
(2005). Investigating the extent of commercial activity in schools. Edinburgh: Scottish Executive Education Department.

Wilson, J. (2002). The sponsorship scam. In E. Lubbers (Ed.), Battling big business: Countering greenwash, infiltration and other forms of corporate bullying (pp. 44-52). Melbourne: Scribe Publications.

Wolcott, Jennifer. (2004, April 28). Hey Kid - You Wanna Buy a ... The Christian Science Monitor.

<www.csmonitor.com/2004/0428/p11s01-lifp.htm>

(Accessed February, 2006).

Young, D. (1996). Building your company's good name: How to create and protect the reputation your organisation wants and deserves. New York: American Management Association.

\section{The author}

David Stuart completed a PhD through Victoria University of

Wellington in 2005, examining the recent history of school-business relationships in New Zealand since 1990. The thesis included a case study of the food industry presence in New Zealand schools. David currently works at the Ministry of Education as a senior research analyst, focussing on research and evaluation of e-learning in New Zealand schools. 